\title{
THE EFFECT OF ORAL CASTOR OIL ON THE DISPOSITION OF METHYPRYLON IN INTOXICATED DOGS
}

\author{
Peter R. Gwilt, Marvin C. Pankaskie and Joseph J. Mitala
}

\begin{abstract}
Clinical observations indicate that large oral doses of castor oil are effective in reducing the time of coma resulting from acute intoxication with lipophilic drugs. It has been further suggested that the rate of removal of these drugs from the body is increased by castor oil. In order to investigate the effect of castor oil on the disposition of lipophilic drugs, five dogs were given toxic doses of methyprylon by intravenous infusion. Each dog was treated with a large oral dose of castor oil in a cross-over fashion. No significant difference was observed in the sleep times of the dogs treated with castor oil, or in the methyprylon pharmacokinetics compared to controls.

It was concluded that castor oil does not affect the disposition of methyprylon.
\end{abstract}

KeY WoRds: Pharmacokinetics, lipophilic drugs; methyprylon, castor oil.

THE LENGTH OF COMA resulting from overdose with lipophilic sedatives and hypnotics bears a close relation to complication rate, the most important of which is respiratory infection. ${ }^{1}$ Consequently, specific measures to enhance the elimination rate of the drug from the body often accompany supportive treatment. For liphophilic drugs, procedures such as haemodialysis, haemoperfusion or forced diuresis are usually ineffective, since most of the drug is located in the tissues and serum concentrations are low.

A novel approach to increasing the elimination rate of lipophilic drugs has been suggested by Diamond, et al. ${ }^{1,2}$ These investigators observed that patients overdosed with methyprylon had a significantly shorter coma time when treated with large oral doses of castor oil compared to matched patients who did not receive castor oil. The effect of the castor oil was attributed to a reduction in the extent of absorption and to an increase in the elimination rate of methyprylon, the latter effect being due to the drug diffusing from the circulation into the castor oil in the bowel lumen.

Animal studies were done to evaluate further effect of the castor oil on the absorption and disposition of another lipophilic drug, ethchlorvynol.' Serum drug concentrations were

Peter R. Gwilt, Ph.D., Marvin C. Pankaskie, Ph.D. and Joseph J. Mitala, Ph.D.,* School of Pharmacy, Ferris State College, Big Rapids, Michigan 49307, U.S.A

*Present Address: Adria Laboratories, Inc., P.O. Box 16529, Columbus, OH 43216.

Can. Anaesth. Soc. J., vol. 29, no. 4, July 1982 lower in animals treated with castor oil compared to controls. Although this may be largely explained by a reduction in drug absorption, it was also observed that the oral castor oil treatment reduced the elimination half-life by approximately 30 per cent in dogs receiving either $150 \mathrm{mg} \cdot \mathrm{kg}^{-1}$ or $300 \mathrm{mg} \cdot \mathrm{kg}^{-1}$ ethchlorvynol. This finding compares with other reports in the literature demonstrating the ability of various orally administered sequestering agents to enhance the total body clearance of certain drugs $s^{3,4}$ and fat-soluble environmental toxins. 5,6

Unfortunately, in' the experiment described, both the drug and the castor oil were administered orally, making it difficult to ascertain the relative effect of the castor oil upon the absorption and the disposition of the drug. Because of the encouraging clinical results reported by Diamond, et al. ${ }^{1}$ and others, ${ }^{2}$ and the difficulties in interpreting the results of their animal experiments ${ }^{1}$ the present investigation was undertaken to clearly evaluate the effect of castor oil on the distribution and elimination of methyprylon in animals.

\section{Materials and Methods}

Five female beagle dogs, each weighing about $10 \mathrm{~kg}$ were used. At least one week before the experiment a cannula was inserted into the right jugular vein of each dog as described by Mitala and Erickson. ${ }^{7}$ At the time of experiment 150 $\mathrm{mg} \cdot \mathrm{kg}^{-1}$ of methyprylon was infused through the cannula over a 10 minute period. Patency of the 381 
cannula and hydration of the dog were maintained by slow intravenous drip of Normosol R in D5W. Drug was administered to each dog twice with at least a week between infusions. Using a cross-over design, one of the two treatments included $10 \mathrm{ml} \cdot \mathrm{kg}^{-1}$ castor oil administered orally one hour after infusion. Sleep time was measured as the time between the loss and regaining of righting reflex of the dog.

Immediately before the methyprylon infusion a blood sample was drawn. Additional blood samples were obtained at $5 \mathrm{~min}, 20 \mathrm{~min}, 30 \mathrm{~min}$, $1 \mathrm{hr}, 2 \mathrm{hr}, 3 \mathrm{hr}, 4 \mathrm{hr}$, and $6 \mathrm{hr}$ after the end of the infusion. Plasma was separated and frozen until the time of assay.

Methyprylon and its major metabolite (3,3diethyl-5 methyl-1,2,3,4-tetrahydro-2,4-piperidinedione) were assayed by high pressure liquid chromatography. To $2 \mathrm{ml}$ of plasma, $25 \mu \mathrm{l}$ of internal standard $(3.0 \mathrm{mg}$ pyrithylidione $/ 250$ $\mathrm{ml}$ distilled water) was added. The drug, metabolite and internal standard were extracted into 10 $\mathrm{ml}$ ether which was then evaporated to dryness in a stream of nitrogen. The residue was dissolved in $25 \mu$ l of the mobile phase of the HPLC (hexane/tetrahydrofuran/ethanol, 930:50:20) and injected onto the column. Details of the assay are to be published elsewhere.

Plasma drug concentration-time data were fitted to a two compartment pharmacokinetic model using NONLIN. ${ }^{8}$

\section{Results AND Discussion}

Sleep times of dogs receiving intravenous methyprylon alone and methyprylon followed by oral castor oil are shown in Table I. Statistical analysis of the data failed to support any significant difference between the two sets of sleep times. Average pharmacokinetic parameters for methyprylon in controls and dogs treated with castor oil are reported in Table II. No statistically significant difference was observed between any pair of parameters. Castor oil, therefore appears to have no effect upon the distribution or the rate of elimination of methyprylon in the dog.

These results appear to conflict with the findings of Diamond, et al. ${ }^{1}$ with ethchlorvynol. However visual examination of the serum drug concentration-time data (Figure 2 in their paper) suggests that in the dogs not treated with castor oil, absorption of the drug continues for approximately 30 hours. A useful determination of the half-life can only be made using data points after this time. When these later points only are
TABLE I

EFFECT OF CASTOR OIL ON METHYPRYLON SLEEP TIME

\begin{tabular}{ccc}
\hline \hline & \multicolumn{2}{c}{ Sleep time (hr) } \\
\cline { 2 - 3 } Dog & Control & Castor oil \\
\hline 1 & 5.20 & 8.0 \\
2 & 5.47 & 4.08 \\
3 & 3.25 & 6.08 \\
4 & 11.23 & 8.50 \\
5 & - & $-^{*}$ \\
Mean \pm S.E. & $6.29 \pm 1.72 \dagger$ & $6.66 \pm 1.01 \dagger$ \\
\hline
\end{tabular}

*Sleep times for Dog 5 not recorded.

†Not statistically significant $(\mathrm{p}>0.5)$ using the paired t-test $(\mathrm{N}=4)$.

used to determine the half-life, the value of this parameter in dogs not treated with castor oil is the same as that in the dogs receiving castor oil, indicating that castor oil treatment has no effect on the elimination rate of ethchlorvynol. The data of these investigators also suggest that while castor oil clearly reduces the extent of absorption, paradoxically it appears to increase the rate of absorption, since absorption appears to be complete by about 15 hours in the dogs receiving castor oil. This may be due to stimulation of gastrointestinal motility by the castor oil or simply increased gastric emptying resulting from the administration of a large volume of fluid. ${ }^{9}$

\section{ConCLUSION}

Both the results of the present investigation with methyprylon and the re-evaluated findings of a previous study with ethchlorvynol suggest that orally administered castor oil does not affect the elimination rate of lipophilic drugs. The dramatic clinical improvement observed in patients treated with castor oil for lipophilic drug overdose may be attributed to the effect of castor oil on the extent of absorption of these drugs.

Castor oil is widely recognized as a useful agent in the treatment of lipophilic drug overdose. ${ }^{10}$ It is important to understand the mechanism of action of this agent to ensure its rational use. The present study indicates that if most of the ingested dose of lipophilic drug has been absorbed, (as in the case of a liquid dosage form such as an elixir) castor oil will not bring about a reduction in the amount of drug in the body. A possible exception to this would be in the treatment of overdose with drugs which undergo enterohepatic cycling. ${ }^{3}$ 
GWILT, et al.: EFFECT OF ORAL CASTOR OIL ON METHYPRYLON

TABLE II

EfFect of Castor Oil on Methyprylon Pharmacokinetics

\begin{tabular}{lcc}
\hline \multicolumn{1}{c}{ Parameter } & $\begin{array}{c}\text { Control* } \\
(\mathrm{N}=5)\end{array}$ & $\begin{array}{c}\text { Caster oil } \\
(\mathrm{N}=5)\end{array}$ \\
\hline$\alpha\left(\mathrm{hr}^{-1}\right)$ & $7.43 \pm 2.81$ & $9.71 \pm 3.53$ \\
$\beta\left(\mathrm{hr}^{-1}\right)$ & $0.23 \pm 0.05$ & $0.21 \pm 0.03$ \\
$\mathrm{~K}_{10}\left(\mathrm{hr}^{-1}\right)$ & $1.30 \pm 0.62$ & $1.45 \pm 0.66$ \\
$\mathrm{~K}_{12}\left(\mathrm{hr}^{-1}\right)$ & $4.81 \pm 2.17$ & $6.64 \pm 3.09$ \\
$\mathrm{~K}_{21}\left(\mathrm{hr}^{-1}\right)$ & $1.83 \pm 0.30$ & $1.55 \pm 0.41$ \\
$\mathrm{~V}_{1}$ (liter) & $3.50 \pm 1.36$ & $3.11 \pm 1.55$ \\
$\mathrm{Vd}_{\beta}$ (liter) & $9.37 \pm 1.71$ & $7.85 \pm 0.58$ \\
Vdss (liter) & $8.37 \pm 1.64$ & $7.11 \pm 0.58$ \\
Total clearance (liter/hr) & $2.09 \pm 0.51$ & $1.95 \pm 0.33$ \\
Total area under plasma- & & \\
time curve, (mg hr/liter) & $1105.61 \pm 430.34 \dagger$ & $940.19 \pm 218.46 \dagger$ \\
\hline
\end{tabular}

*Figures in columns are means \pm 1 standard error of the mean.

$\dagger$ No statistically significant difference was observed at the 0.05 level between any pair of parameters using the paired t-test.

\section{ACKNOWLEDGEMENTS}

This work was supported by a Ferris State College Faculty Research Grant. The assistance of Dr. Gerald W.A. Slywka and Messrs. John Jameson, Robert Riffert and Greg Wellman is gratefully acknowledged.

\section{REFERENCES}

1. Diamond, M.J., Brownstone, Y.S., Ereg, G., Kieraszewicz, H. \& KeERI-Szanto, M The reduction of coma time in lipophilic drug overdose using castor oil. Canad. Anaesth. Soc. J., 23: 170 (1976).

2. ANON. To flush drug overdose, castor oil. Med. World News 16: 43 (1975).

3. Neuvonen, P.J. \& Elonen, E. Effect of activated charcoal on absorption and elimination of phenobarbitone, carbamazepine and phenylbutazone in man. Eur. J. Clin. Pharmacol 17:51 (1980).
4. Caldwell, J.H. \& Greenberger, N.J. Interruption of the enterohepatic circulation of digitoxin by cholestyramine. I. Protection against lethal digitoxin intoxication. J. Clin. Invest. 50: 2626 (1971)

5. Richter, E., Lay, J.P., Klein, W. \& Korte, F. Enhanced elimination of hexachlorobenzene in rats by light liquid paraffin. Chemosphere 6 : 357 (1977).

6. Richter, E., LAY, J.P., KLEIN, W. \& KorTe, F. Enhanced elimination of Kepone- ${ }^{14} \mathrm{C}$ in rats fed liquid paraffin. J. Agric. Food Chem. 27: 187 (1979).

7. Mitala, J.J. \& Eruckson, S.R. Method for repetitive blood sampling in the dog: a modification. J. Pharmacol. Meth. 5: 185 (1980).

8. Metzler, C.M., Elfring, G.L. \& McEwen, A.J. A users manual for nonlin and associated programs. The Upjohn Co., Kalamazoo (1974).

9. CHIN. L. Gastrointestinal dilution of poisons with water - an irrational and potentially harmful procedure. Am. J. Hosp. Pharm. 28: 712 (1971).

10. Arena, J.M. Poisoning: Toxicology, Symptoms, Treatments, 3rd ed., Charles C. Thomas, Springfield, IL, p. 354 (1970).

\section{RÉSUMÉ}

Des observations cliniques montrent que l'huile de ricin administrée à fortes doses par voie orale est efficace pour abréger la durée du coma causé par une intoxication aiguë aux agents lipophiliques. Il a de plus été suggéré que la vitesse d'élimination de ces agents est accélérée par l'huile de ricin. Notre travail effectué chez le chien avait pour but de vérifier cette assertion. A cette fin, cinq animaux ont reçu dans un premier temps des doses toxiques de methyprolon par voie intraveineuse, suivies de l'administration par voie orale de $10 \mathrm{ml} / \mathrm{kg}$ d'huile de ricin; l'expérience a été reprise sur chacun des chiens, une semaine plus tard, en omettant cette fois-ci la dose d'huile de ricin après le methyprolon. On n'a pas trouvé de différence significative entre les durées de sommeil et les données pharmakynétiques de methyprolon, et ceci, que les animaux aient reçu ou non de l'huile de ricin. Il est conclu que ce médicament ne modifie pas l'élimination du methyprolon. 